A. Goroshko, T. Derkach, T. Dmitrenko, A. Dmitrenko

Poltava National Technical Yuri Kondratyuk University, Poltava, Ukraine

\title{
ASSESSMENT OF SOCIO-ECONOMIC VALUE AND EFFICIENCY OF AUTHOR'S SOFTWARE AND HARDWARE SYSTEM
}

\begin{abstract}
The main goal of the article is to study and analyze the functional software and hardware complex application areas, as well as to assess the socio-economic significance and effectiveness of the developed software and hardware complex. Summary. As a study result, the following conclusions were obtained: 1 . The implementation effectiveness of a particular invention, project or rationalization proposal is based on taking into account the results and costs incurred to achieve them and the economic feasibility of the proposed solution to the problem. 2. Cost estimation model - COCOMO II and similar models are suitable for automatically calculating the software product cost with a large number of code lines. 3. FSA is the most effective way to determine the economic software and hardware systems feasibility, where you need to take into account the author's device material component itself. 4. The developed author's software and hardware complex will have an economic effect from the introduction in the first year of its use both for the manufacturer or consumer, and for the state as a whole.
\end{abstract}

Keywords: software and hardware complex, intellectual potential, intellectual capital, functional-cost analysis (PSA).

\section{Introduction}

Nowadays in Ukraine, IT professionals are relevant to carry out appropriate calculations to assess the economic importance and effectiveness of software product development necessary to promote innovation on the market. At the present stage, intangible and innovative-intellectual components, which include software products, the quality of server services, and the like, occupy an increasing share in the structure of the value of goods.

The development of information technologies, their deep penetration into the production process, a decisive increase in the role and importance of the human mind, science, information and knowledge in the economy and society development as a whole, contributed to the intellectual capital emergence. At the present stage, most world countries determine the priorities of their nation intellectual capital development. Recently, it is the nation's intellectual capital that is increasingly becoming a leading factor in economic growth and international exchange, radical structural changes, and has become the main factor in determining the market value of high-tech companies and the formation of a competitiveness high level. Based on this, it can be argued that a qualitatively new type of economy is emerging in the modern world - an economy based on knowledge and the artificial intelligence use.

It is well known that leading countries ensure their development through knowledge-based innovationoriented industries. The formation of Ukraine as an independent and economically independent state is based on the formation of a new world economic development model - the knowledge economy [1]. The knowledge economy concept has recently become an important theoretical, methodological and scientificpractical basis for the economic growth of many countries. It reveals the new human intelligence role and place in society. In connection with the technological development accelerated pace, the knowledge availability is becoming an essential condition for a country's participation in global competition. The current social and economic development state of society requires the intellectual capital preparation as one of the innovative development priorities.

For the needs of the country's innovative development, education plays an extremely important role and is the key to the accumulation of intellectual capital. It is not only a connecting, but also a constructive link in the system of the main components of an innovative economy - "science-educationproduction". In combination, the educational potential acts both as a source of replenishment of highly qualified personnel and as the main factor in mastering the population of modern knowledge.

The mastery level of modern knowledge directly affects the educational potential, which in turn leads to an increase in the state intellectual potential. Preserving the student health during the educational process is great importance for the our state future. Recently, the increased young people fatigue during the educational process leads to an increase in the treatment cost, first aid, risk of accidents, etc. [2,3]. Therefore, a hardwaresoftware complex for determining human fatigue was created, which provides high accuracy and flexibility of a diagnostic operation to determine the person functional state. It is characterized by convenience and simplicity in its use and has the ability to remotely change the frequency-pulse and color-light characteristic, which consists of a simple electronic component base.

However, it is well known that the any invention effectiveness, project or software development is based on taking into account the results and costs incurred to achieve them and the economic feasibility of the proposed solution to the problem.

\section{Analysis of recent research and publications}

The intensive research beginning of models for estimating the software products cost dates back to the 60 s of the last century, when E.A. Nelson, an employee of System Develop-C ment Corporation (SDC), published his first paper [5]. After the book publication - in the late $60 \mathrm{~s}$ - early $70 \mathrm{~s}$ - a fairly large assessment models number appeared (Delphi, Wolverton, etc.). 
The Delphi model was created by Rand Corporation back in 1940, but the research results were published only in the seventies. TRW employee model R.U. Volverton, who later became, together with a group of other researchers, the creator one of the most widely used cost estimation models - COCOMO, which was released in 1974 [6].

The first commercial product for evaluating the software project cost appeared in 1977, it was the PRICE-S model developed by the staff of Martin Marietta Price Systems F. Freimen and Dr. R. Park [7]. A little later, in 1978, a second commercial model appeared - SLIM, created by Quantitative Software Management, Inc. (QSM).

By the end of the 70s - beginning of the $80 \mathrm{~s}$, a number of serious models appeared - such as SEER, ESTIMACS. In 1981, Dr. Barry Bohem, a researcher, director of the Center for System and Software at the University of Southern California, proposed his COCOMO model (The COnstructive COst MOdel - a constructive cost model), which was based on the counting lines code metric [8]. It has become one of the most popular due to its accuracy and calibration capabilities for various projects. In 1995, an updated model version was published [9]. In the eighties, large organizations such as the Rome Air Development Center (RADC) and NASA joined in the cost estimation problem study.

\section{Purpose of the article}

The main goal of the study is to analyze the socioeconomic assessment significance and effectiveness of the developed author's hardware and software complex [10-13].

\section{The main part of the article}

At the present society development stage, in the rapid development era of information technology, the number of high-budget projects in the software development field is constantly growing, and therefore it becomes very important to be able to assess the project benefits and losses at various development stages, to analyze possible scenarios of the events development. According to statistics, about a quarter of all started projects are completed in a timely manner, a quarter is canceled and about half of all projects are completed in budget expenditures excess or delayed. Most of the reasons are related to the project incorrectness cost estimates, which makes this direction one of the most important. The selected model and software should be tested on real projects in order to identify discrepancies between the values obtained on the model basis and software and the actual values for the project. Based on the results obtained, it can be concluded that it is advisable to use selected models and software as a cost estimation model. In case of discrepancies, it is necessary to find a way to eliminate them, to determine the model improving possibility, improving the estimates accuracy.

To assess the invention effectiveness of the indirect evaluation hardware-software complex methods are used. It is clear that reducing fatigue will increase the assimilation rate of educational material, improve the training and maintain health quality of young people, which in turn will reduce the treatment cost and etc. The one person training cost in a comprehensive school for the state is 3000 hryvnias. This value is obtained taking into account the health costs protection and disease prevention and it is $10-15 \%$, that is, 300-450 hryvnia. If the proposed inventions will reduce the incidence of eyes, scoliosis or other organs by $5 \%$, then the annual savings per person will be 15 UAH If you take it on a countrywide basis, you can easily calculate the total savings by producing a certain amount by the total number of students, that is, 4,299 thousand. People will give 64.5 million UAH. saving.

The next step to solve the problem was to calculate the hardware-software complex costs for measuring the functional state. In order to improve the quality and consumer software and hardware complex properties at all stages of the life cycle, a functional cost analysis (FSA) was applied. Functional-cost analysis is an effective method for determining the cost and other products and services characteristics, which is based on the functions resources involved use and in the production, marketing, sale, delivery, technical support, services, customer service, and quality assurance. This method was first used by General Motors (USA) in 1947. The method is widely used in the USA, England, Japan and other countries. The method of an innovative object comprehensive technical and economic study in order to develop and improve its useful functions with the optimal ratio between their importance for the consumer and the implementation cost is perfectly developed and described in the literature. So, the main purpose of the FSA is to help reduce the production cost, work and services while improving or maintaining the achieved quality of work performed at all stages. Mathematically, the FSA method can be represented by the formula:

$$
\frac{C B}{B} \Rightarrow \max
$$

where SB is the use value of the software package, which is a consumer properties combination (total cost); $\mathrm{B}$ - the cost of achieving the necessary consumer properties. The software product in question is a product, that is, a use value, not for the manufacturer, but for the consumer. The consumer software product value can be estimated using both quantitative indicators and relative scores, which are used for a qualitative and complex description (assessment of the aesthetic and visual qualities of software solutions).

In our study, we lay the foundation of the FSA on such principles as a functional approach, that is, object study consideration taking into account the functions for which it is created; valuation, is a continuous economic evaluation of emerging software solutions; systematic approach to the FSA software solution; full achievements of computer science and heuristics, etc.

FSA methodological principles are presented in Fig. 1. The tasks and features described above should be carried out during the life cycle of the software product, for management and health purposes it can be divided into stages. 


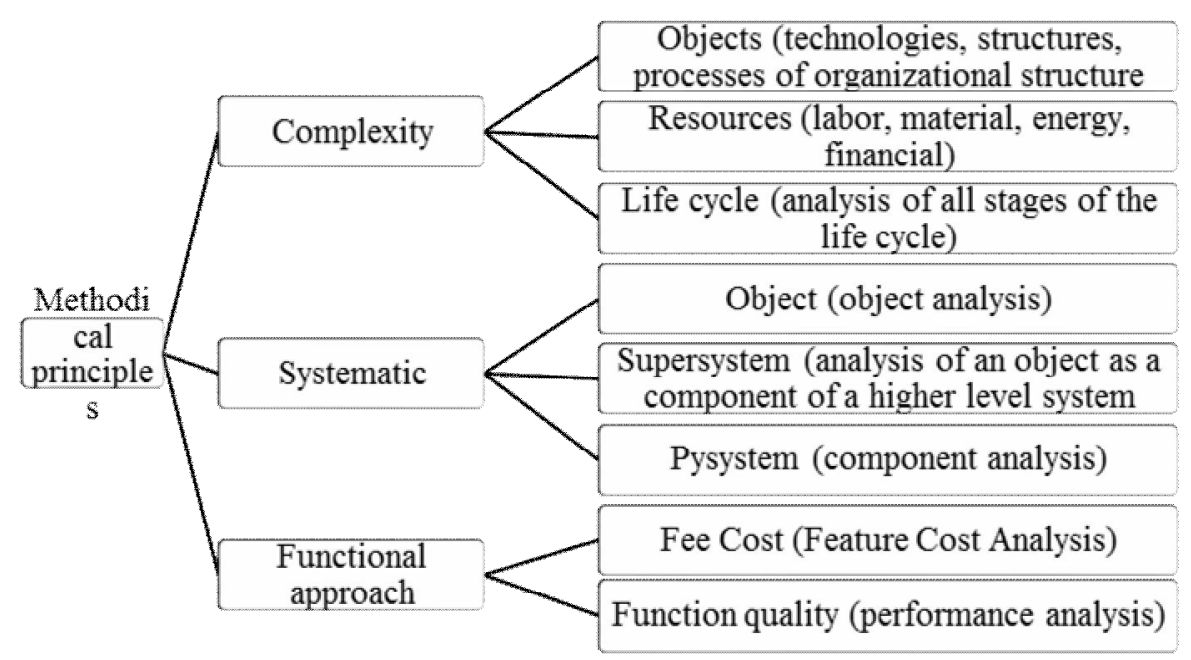

Fig. 1. FSA methodological principles

The actions and stages sequence of the life cycle of the developed hardware-software complex is shown in Fig. 2.

Functional and cost software product analysis consists of a set of interrelated activities aimed at creating conditions for the organization of work for its preparation and conduct.

For a detailed analysis of consumer properties of a software product, its technical functions, as well as the functions of its individual parts related to their manufacture, it is necessary to attract various specialists. It is impossible to conduct a comprehensive analysis by the forces of one or a small group of specialists, for this we need appropriate specialists: developers, designers, economists, marketers, innovation managers, etc.

The conducting process a software product functional-cost analysis consists of the following stages: preparatory; informational; research; analytical; recommendatory; innovative.

At the first, preparatory stage, it is necessary to determine the analysis object and develop organizational forms for conducting the FSA. At the analytical stage, information is collected and systematized on the object functional structure and on the material carriers of its individual functions. As a study result, it was at the analytical stage that the technical, economic, operational, ergonomic and aesthetic object functions as whole and additional technical functions were examined in detail. As you know, in an analytical study, an object is considered as a set of functions that it performs. Among these functions, some are basic, since they stem from the purpose of the object, the second are auxiliary, because they create conditions for the implementation of the basic functions, and the third functions are superfluous, that is, they are not needed at all. The proportion of individual functions in the total set of consumer object properties is determined by the importance coefficient or significance. When determining this coefficient, the most important characteristics for the consumer are taken into account (table 1).

The table computes and shows the cost coefficients for each individual function.

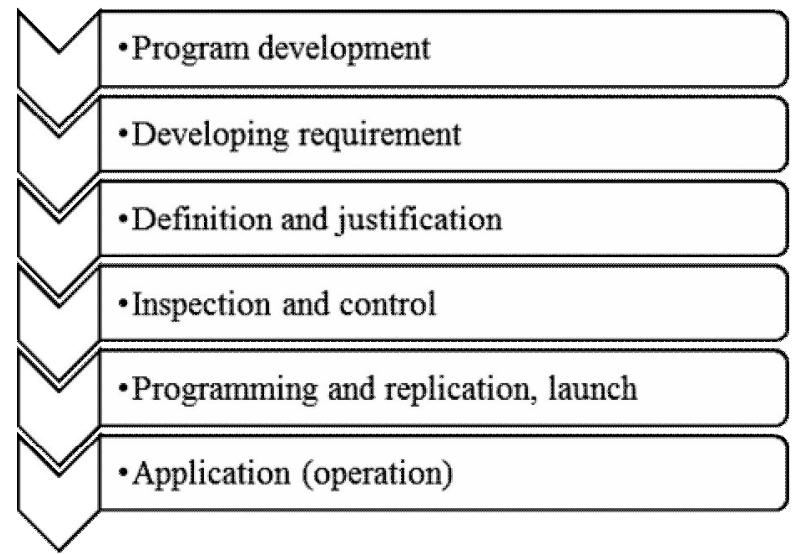

Fig. 2. The actions and stages sequence of the life cycle of the developed hardware-software complex

In general terms, this coefficient is equal to the ratio of the function specific gravity in expenses in the function significance. An important parameter in the table is the first one for which:

$$
K_{\Phi_{1}}=\frac{70}{50}=1,4>1
$$

This coefficient indicates a mismatch between the costs and function significance, usually it should be equal to 1 . If the cost coefficient is less than 1 , the ratio is considered favorable, and if the value is more than 1 , it is recommended to reduce costs.

The search for the most rational solutions was carried out from the implementation perspective of the studied functions and ensuring the requirements for the object performance. The solution options feasibility study is carried out according to the documents in force in the economic efficiency field. Using the proposed methods, the developed hardware-software complex was tested by both the author and the Ministry of Economic Development [10, $11]$.

The main criterion for the rational decisions selection was the maximum beneficial effect value per unit of total costs for the manufacture and operation of the object, increasing its competitiveness and increasing profits from its implementation. 
Table 1-Comparison of significance coefficients and the functions parameters expenses share

\begin{tabular}{|c|c|c|c|}
\hline Functions & $\begin{array}{c}\text { Signi- } \\
\text { ficance, } \\
\%\end{array}$ & $\begin{array}{c}\text { The function } \\
\text { share in } \\
\text { costs, } \%\end{array}$ & $\begin{array}{l}\text { Function } \\
\text { Cost Ratio }\end{array}$ \\
\hline \begin{tabular}{|l|} 
Performance \\
Indicators Естета \\
\end{tabular} & 50 & 70 & 1,4 \\
\hline Power consumption & 25 & 10 & 0,4 \\
\hline Ergonomics & 15 & 10 & 0,67 \\
\hline Information content & 10 & 10 & 1 \\
\hline Total & 100 & 100 & - \\
\hline
\end{tabular}

The functional model was built using several levels. Each functions level has its purpose.

At the upper (first) level, the study object external functions are located, they are performed by the object as a whole. At the second level - the main functions. The third and fourth levels are designed to accommodate the study object auxiliary functions.

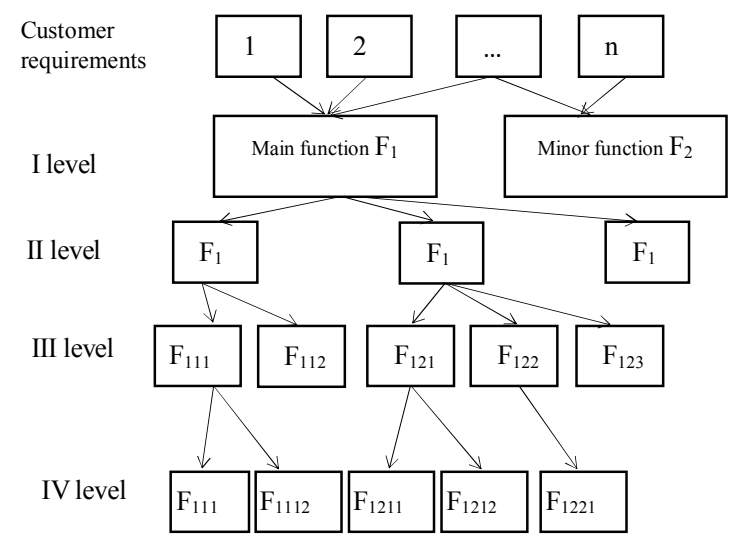

Fig. 3. Functional Model Diagram

When evaluating the functions values having a vertex at a higher functional model level, the main condition is the equality:

$$
\sum_{i=1}^{n} a_{j}=1,
$$

where is $a_{j}-$ a value $j$-i functions; $i=1 \ldots \mathrm{n}-$ the number of given level functions having a common vertex.

Along with the function name, the value aj is placed on the functional model. The functional model has a multi-stage structure, where the function value of any level (RFij) as a whole is proposed to be determined by the following formula:

$$
\mathrm{R}_{\mathrm{F}_{\mathrm{ij}}}=\prod_{\mathrm{I}}^{\mathrm{G}} \mathrm{a}_{\mathrm{F}_{\mathrm{ij}}} \text { при } 0<\mathrm{a}_{\mathrm{F}_{\mathrm{ij}}}<1,
$$

Where is $a_{\mathrm{Fij}}-\mathrm{a}$ value $\mathrm{i}-\mathrm{i}$ functions $\mathrm{j}-$ th level; $\mathrm{G}-$ the number of functional model levels.

In the upper right corner, the numbers indicate the function value in relation to the higher level function value. The determination of the software solution functions values in a functional model is presented in Fig. 4.

In accordance with the functional model, first of all, were calculated values of the main and functions, based on their providing role the object needs.

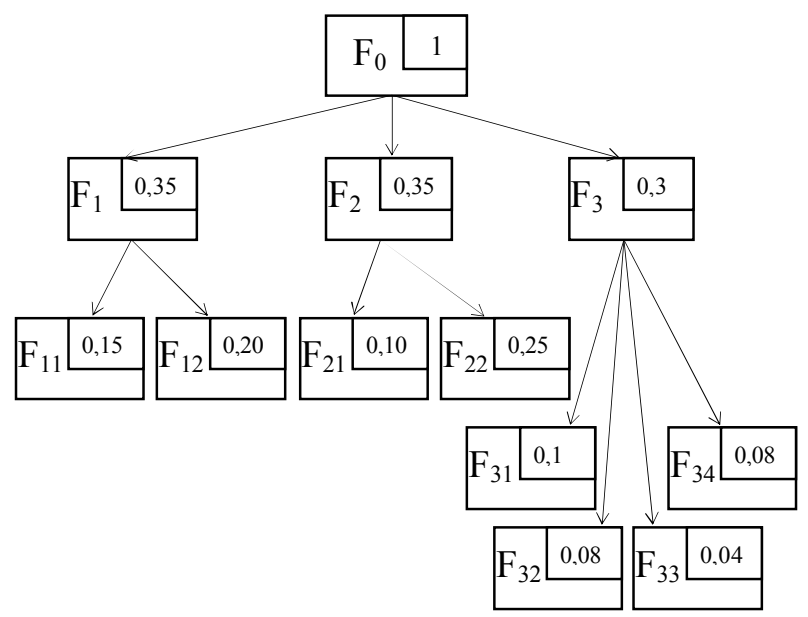

Fig. 4. Determining the software solution functions values in a functional model

Secondly, the functions values, based on the implementation role of the main and auxiliary functions. The sum of the main functions $\left(\mathrm{F}_{1}, \mathrm{~F}_{2}, \mathrm{~F}_{3}\right)$ is equal to one and equal to the value of the main function $\left(\mathrm{F}_{0}\right)$. The sum of the auxiliary functions values $\left(\mathrm{F}_{11}, \mathrm{~F}_{12}\right)$ is equal to the function value $\left(\mathrm{F}_{1}\right)$. So, the function $\mathrm{F}_{1}=$ 0.35, and its components $\mathrm{F}_{11}=0.15$ and $\mathrm{F}_{12}=0.20$.

Thus, we have: $F_{11}+F_{12}=F_{1} ; 0,15+0,20=0,35$.

Similarly, we get the value $\mathrm{F}_{2}$, namely:

$\mathrm{F}_{21}+\mathrm{F}_{22}=\mathrm{F}_{2} ; 0,10+0,25=0,35$.

Accordingly, if $\mathrm{F}_{31}=0,1 ; \mathrm{F}_{32}=0,08 ; \mathrm{F}_{33}=0,04$;

$\mathrm{F}_{34}=0,08$, and $\mathrm{F}_{3}=0,3$, thus we have an expression: $\mathrm{F}_{31}+\mathrm{F}_{32}+\mathrm{F}_{33}+\mathrm{F}_{34}=\mathrm{F}_{3} ; 0,1+0,08+0,04+0,08$ $=0,3$.

As noted above, the value of the main function is unity $\left(\mathrm{F}_{0}=1\right)$, so:

$\mathrm{F}_{1}+\mathrm{F}_{2}+\mathrm{F}_{3}=\mathrm{F}_{0} ; 0,35+0,35+0,3=1$.

The procedure for determining actual costs includes: the material carriers proportion in the function implementation; the costs share determination of creating each material carrier that falls on this function; summing the function costs for all tangible media.

In order to determine the share of each material carrier in the identified functions implementation by comparing the functional and structural models, a functional - structural model (FSM) was built. To build it, a graphic form was used. For each function, a detailed analysis was carried out to identify its usefulness.

The carried out cost calculation made it possible to determine the approximate annual economic effect of the development implementation, which in turn allowed us to draw conclusions about the using appropriateness the proposed version of the hardware-software complex. According to the analysis results, the estimated annual economic effect from the development implementation is $152,000 \mathrm{UAH}$. The proposed complex version will reduce the manufacturing complexity by 128600 standard hours and reduce the indirect maintaining health cost by 64500000 . UAH. (The calculation is made for students of a comprehensive school).

\section{Conclusion}

1. The implementation effectiveness of a particular invention, project or rationalization proposal is based on 
taking into account the results and costs incurred to achieve them and the economic feasibility of the proposed solution to the problem.

2. Cost estimation model - COCOMO II and similar models are suitable for automatically calculating the software product cost a with a large number of code lines.

3. Functional-cost analysis is the most effective way to determine the economic software and hardware systems feasibility, where you need to take into account the material component of the author's device itself.

4. The developed software and hardware complex will be economically profitable when implemented in the first year of its use for the state, manufacturer and consumer.

\title{
REFERENCES
}

1. Postanova Verkhovnoi Rady Ukrainy vid 3 liutoho 2011 roku N 2992-VI:Pro Rekomendatsii parlamentskykh slukhan pro stanovyshche molodi v Ukraini "Molod za zdorovyi sposib zhyttia"// Vidomosti Verkhovnoi Rady Ukrainy. - 2011.- N 24. S. 17.

2. Goroshko A. Problems of fatigue of modern youth / A. Goroshko // Ecology is a plus. - 2011. - №5. - p. 6-13.

3. A. Goroshko, T. Derkach,T. Dmytrenko Program development for mobile control of functional human condition on android platform / Systems of Control, Navigation and Communication. - Poltava : Poltava NTU, 2019.- № 2(54). - p. 74-76.

4. Natsionalna stratehiia rozvytku osvity v Ukraini na 2012-2021 roky / Uriad. Port. - [Electronic resource] - Access mode: http://www.kmu.gov.ua/control/publish/articlearid7=245571411.

5. McConnell S. How much does a software project cost / S. McConnell // M.: Peter. -464 pp.

6. Millsup C. Oracle. Performance Optimization/ C. Millsup, D. Holt // Symbol Plus. - 2006. - 464 pp.

7. Fatrell, R. T., Shafer, D. F., \& Shafer, L. I. (2003). Upravlenie programmnymi proektami: dostizhenie optimalnogo kachestva pri minimume zatrat, (Trans. from English). Moscow: Izd. dom "Viliams". 1136 p.

8. Barry W. Boehm. Software cost estimation with COCOMO II. Prentice Hall PTR, 2000.

9. Boehm B, Clark B, Horowitz E, Westland C, Madachy R., Selby R. Software Life-cycle Processes: COCOMO 2.0. // Annals of Software Engineering Special Volume on Software Process and Product, 1995.

10. Pat. 129513 Ukraina, MPK A61B3/00. Prohramno-aparatnyi kompleks po vyznachenniu vtomliuvannosti liudyny /Horoshko A.I., Horoshko O.-I. I.; vlasnyk Horoshko A.I., U2018 06753; zaiavl. 14.06.2018; opubl. 25.10.2018, Biul.№20.

11. Pat. 129512 Ukraina, MPK A61N5/01. Sposib vyznachennia vtomliuvannosti liudyny /Horoshko A.I., Horoshko O.-I. I.; vlasnyk Horoshko A. I., U2018 06752; zaiavl. 14.06.2018; opubl. 25.10.2018, Biul.№20

12. Avt. Pravo №81100 21.08.2018 Kompiuterna prohrama”Mikroprohrama "2A+” dlia prohramno-obchysliuvalnoi platformy Arduino"/Horoshko A.I.

13. Avt. Pravo №81099 21.08.2018 Kompiuterna prohrama”Mobilnyi dodatok” Mobile diagnostical complex — eye fatigue”(“ Mobilnyi dodatok - "MDC-EF") / Horoshko A.I.

Рецензент: д-р техн. наук, доц. О. В. Шефер, Полтавський національний технічний університет імені Юрія Кондратюка, Полтава Received (Надійшла) 23.09.2019 Accepted for publication (Прийнята до друку) 23.10.2019

\section{Оцінка соціально-економічного значення та ефективності авторського програмно-апаратного комплексу}

\author{
А. І. Горошко, Т. М. Деркач, Т. А. Дмитренко, А. О. Дмитренко
}

Основна мета статті полягає в дослідженні і аналізі функціональних областей застосування програмно-апаратного комплексу, а також в оцінці соціально-економічного значення та ефективності розробленого програмно-апаратного комплексу. Висновки: 1. Ефективність реалізації певного винаходу, проекту або раціоналізаторської пропозиції базується на обліку результатів і витрат, понесених для їх досягнення і економічної доцільності запропонованого вирішення проблеми. 2. Модель оцінки вартості - СОСОМО II і подібні моделі придатні для автоматичного підрахунку вартості програмного продукту при великій кількості рядків коду. 3. ФВА - найефективніший спосіб для визначення економічної доцільності програмно-апаратних комплексів, де потрібно враховувати матеріальну складову самого авторського приладу. 4. Розроблений авторський програмно-апаратний комплекс матиме екномічній ефект від впровадження вже в перший рік свого застосування для держави, виробника і споживача.

Кл ючов і слов а : програмно-апаратний комплекс, програмний продукт, функціонально-вартісний аналіз (ФВА).

Оценка социально-экономического значения и эффективности авторского программно-аппаратного комплекса

А. И. Горошко, Т. Н. Деркач, Т. А. Дмитренко, А. А. Дмитренко

Основная цель статьи заключается в исследовании и анализе функциональних областей применения программноаппаратного комплекса, а также в оценке социально-экономического значения и эффективности разработанного программно-аппаратного комплекса. Выводы: 1. Эффективность реализации определенного изобретения, проекта или рационализаторского предложения базируется на учете результатов и расходов, понесенных для их достижения и экономической целесообразности предложенного решения проблемы. 2. Модель оценки стоимости - СОСОМО II и подобные модели пригодные для автоматического подсчета стоимости программного продукта при большом количестве строк кода. 3. ФВА - самый эффективный способ для определения экономической целесообразности программно-аппаратных комплексов, где нужно учитывать материальную составляющую самого авторского прибора. 4. Разработанный авторский программно-аппаратный комплекс будет иметь екномічний эффект от внедрения уже в первый год своего приложения для государства, производителя и потребителя.

Ключевые слова: программно-аппаратный комплекс, программный продукт, функционально-стоимостный анализ (ФВА). 